\title{
ANALISIS RISIKO KECELAKAAN KERJA PADA KEGIATAN RIG SERVICE MENGGUNAKAN METODE HIRARC DENGAN PENDEKATAN FTA
}

\author{
Siti Nurlelyza Trisaid \\ Teknik Industri, Fakultas Sains dan Teknologi, Universitas Al-Azhar Indonesia \\ e-mail: Lelyzats@gmail.com
}

\begin{abstract}
ABSTRAK
PT Pertamina EP adalah anak Perusahaan PT Pertamina (Persero) yang menyelenggarakan kegiatan usaha di sektor hulu bidang minyak dan gas bumi, meliputi kegiatan eksplorasi dan eksploitasi. Sebagaimana kita ketahui sebuah industri yang bergerak dalam bidang minyak dan gas tentunya memiliki risiko bahaya yang cukup tinggi, salah satunya pada kegiatan RIG service, pada pekerjaan menyiapkan semua material dan fasilitas penunjang, mengacu pada sering nya terjadi kecelakaan kerja pada kegiatan RIG service maka, perlu dilakukan identifikasi menyeluruh risiko bahaya, risk level, penyebab hingga dihasilkannya rekomendasi pengendalian khususnya di area RIG service yang dapat membantu dalam mengantisipasi terjadinya kecelakaan kerja. Metode yang digunakan ialah HIRARC dengan pendekatan FTA, kemudian setelah dilakukan analisis menggunakan metode HIRARC dapat diketahui risiko bahaya tertinggi yaitu, terjatuh, terjepit dan terpeleset dengan nilai risk level sebesar 5 dengan kategori tinggi. Kemudian setelah dilakukan analisis lebih lanjut penyebab risiko bahaya yaitu, posisi material atau alat yang tidak sesuai dengan ketentuan dan kurang penerapan pelaksanaan Standar Operational Procedure (SOP) dalam bekerja.
\end{abstract}

Kata kunci: FTA, HIRARC, kecelakaan kerja, risiko bahaya.

\begin{abstract}
PT Pertamina EP is a subsidiary of PT Pertamina (Persero) which carries out business activities in the upstream oil and gas sector, including exploration and exploitation activities. As we know, an industry engaged in the oil and gas sector certainly has a high enough risk of danger, one of which is in RIG service activities, in the work of preparing all material and supporting facilities, referring to the frequent occurrence of work accidents in RIG service activities, it is necessary a thorough identification of hazard risks, risk levels, causes is made, and recommendations for control, especially in the RIG service area, can help anticipate workplace accidents. The method used is the HIRA with the FTA approach, then after analysis using the HIRA method, it can be seen the highest risk of danger, namely, falling, pinched and slipping with a risk level of 5 with a high category. Then after further analysis of the causes of hazard risk, namely, the position of the material or equipment that is not in accordance with the provisions and lack of implementation of the Standard Operating Procedure (SOP) in the work.
\end{abstract}

Keywords: FTA, HIRARC, work accident, hazard risk

\section{PENDAHULUAN}

Dalam mengidentifikasi risiko bahaya banyak metode yang dapat dilakukan, ILO mencata angka kematian di karenakan kecelakaan dan penyakit akibat kerja (PAK) mencapai 2 jt kasus setiap tahun [1]. Salah satunya dengan metode Hazard Identification and Risk Assesment \& Risk Control (HIRARC) [2,3,4,5]. Hazard Identification and Risk Assesment \& Risk Control (HIRARC) merupakan sebuah metode yang terdiri dari identifikasi bahaya, penilaian risiko, dan pengendalian risiko dari seluruh pekerjaan. Selain itu, penilaian resiko juga bisa menggunakan Metode HIRADC Hazard Identification and Risk Assesment \& Determine Control [6].

Sebagai perusahaan tambang minyak dan gas bumi milik negara, PT Pertamina EP Asset 1 Jambi Field memprioritaskan keselamatan dan kesehatan kerja (K3) bagi para pekerja dan mitra kerjanya pada semua kegiatan kerja salah satunya pada RIG service, kegiatan RIG service harus didukung oleh persiapan semua material dan fasilitas penunjang sumur reparasi, perawatan, reaktivasi, dan stimulasi yang siap bekerja serta 
aman. Besarnya risiko bahaya di RIG service pada pekerjaan menyiapkan semua material dan fasilitas penunjang sumur reparasi, perawatan, reaktivasi, dan stimulasi mengacu pada sering nya terjadi kecelakaan kerja pada pada kegiatan RIG service maka perlu dilakukan identifikasi menyeluruh risiko bahaya, risk level, penyebab hingga dihasilkannya rekomendasi pengendalian khususnya di area RIG service yang dapat membantu dalam mengantisipasi terjadinya kecelakaan kerja.Sehingga, berdasarkan gambaran diatas, peneliti akan mengerucutkan masalah dengan menganalisis mengenai identifikasi bahaya, analisis, dan pengendalian risiko bahaya pada kondisi eksisting di PT Pertamina EP Asset 1 Jambi Field dengan peraturan yang berlaku.

Kemudian untuk mencari event-event penyebab terjadinya potensi bahaya, menggunakan metode Fault Tree Analysis (FTA) yang dimaksudkan untuk mencari eventevent penyebab terjadinya kegagalan potensi bahaya pada kegiatan RIG service dan penggunaan metode FTA ditujukan sebagai tool untuk menemukan penyebab potensi bahaya yang terdiri dari kombinasi event-event yang menunjukkan sumber atau penyebab gagalnya suatu event atau kejadian. Penelitian dilakukan dengan melakukan studi lapangan di PT Pertamina EP Asset 1 Jambi Field dan melakukan konsultasi/wawancara terhadap pekerja di Departemen HSSE PT.Pertamina EP Asset 1 Jambi Field maupun pekerja di lapangan.

\section{METODE PENELITIAN}

Dalam Penelitian ini identifikasi bahaya di lakukan dengan menggunakan Metode HIRARC yaitu gabungan dari hazard identification, risk assessment dan risk control merupakan sebuah metode dalam mencegah atau meminimalisir kecelakaan kerja [7]. HIRARC merupakan metode yang dimulai dari menentukan jenis kegiatan kerja yang kemudian diidentifikasi sumber bahayanya sehingga didapatkan risikonya. Kemudian akan dilakukan penilaian risiko dan pengendalian risiko untuk mengurangi paparan bahaya yang terdapat pada setiap jenis pekerjaan. Berdasarkan OHSAS 18001:2007 perencanaan HIRARC mengharuskan organisasi/perusahaan yang akan menerapkan SMK3 melakukan penyusunan HIRARC pada perusahaannya [8]. HIRARC dibagi menjadi 3 tahap yaitu identifikasi bahaya (hazard identification), penilaian risiko (risk assesment), dan pengendalian risiko (risk control).

\section{Identifikasi Bahaya (Hazard Identification)}

Identifikasi bahaya adalah upaya sistematis untuk mengetahui potensi bahaya yang ada di lingkungan kerja. Tanpa mengenal bahaya, maka risiko tidak dapat ditentukan, sehingga upaya pencegahan dan pengendalian risiko tidak dapat dijalankan [9].

\section{Penilaian Risiko (Risk Assesment)}

Setelah melakukan identifikasi bahaya dilanjutkan dengan penilaian risiko. Penilaian risiko ini bertujuan untuk mengevaluasi besarnya risiko serta mempertimbangkaan kemungkinan dampak yang akan ditimbulkannya. Berdasarkan hasil analisis dapat ditentukan peringkat risiko sehingga dapat dilakukan pemilahan risiko yang memiliki dampak kecil hingga besar. Hasil analisis risiko dievaluasi dan dibandingkan dengan kriteria yang telah ditetapkan atau standar yang berlaku. Apabila risiko masih berada di atas batas yang dapat diterima, maka harus dilakukan langkah pengendalian [9]. Penilaian risiko (Risk Assessment) mencangkup 2 tahapan, yaitu menganalisis risiko dan mengevalasi risiko, dimana evaluasi risiko merupakan hasil yang digunakan untuk menilai apakah risiko tersebut dapat diterima atau tidak, dengan membandingkan terhadap standar yang berlaku. 


\section{Pengendalian Risiko (Risk Control)}

Pengendalian risiko dilakukan terhadap seluruh bahaya yang ditemukan dalam proses identifikasi bahaya dan mempertimbangkan peringkat risiko untuk menentukan prioritas dan cara pengendaliannya.Pengendalian risiko merupakan langkah menentukan dalam keseluruhan manajemen risiko. Berdasarkan hasil analisa dan evaluasi risiko dapat ditentukan apakah suatu risiko dapat diterima atau tidak. Jika risiko dapat diterima, tentunya tidak diperlukan langkah pengendalian lebih lanjut [9]. Berkaitan dengan risiko $\mathrm{K} 3$, pengendalian risiko dilakukan dengan mengurangi kemungkinan atau keparahan dengan mengikuti 5 hirarki sebagai berikut: 1) Eliminasi (Elimination) merupakan suatu pengendalian risiko yang bersifat permanen dan harus dicoba untuk diterapkan sebagai pilihan prioritas pertama, 2) Substitusi (Substitution), untuk menggantikan bahan-bahan dan peralatan yang lebih berbahaya dengan bahan-bahan dan peralatan yang kurang berbahaya atau yang lebih aman, sehingga pemaparannya selalu dalam batas yang masih dapat diterima, 3) Rekayasa Teknik (Engineering Control), pengendalian atau rekayasa teknik termasuk merubah struktur objek kerja untuk mencegah seseorang terpapar kepada potensi bahaya, 4) Pengendalian Administrasi (Administration Control), dilakukan dengan menyediakan suatu sistem kerja yang dapat mengurangi kemungkinan seseorang terpapar potensi bahaya, 5) Alat Pelindung Diri (Personal Protective Equipment) secara umum merupakan sarana pengendalian yang digunakan untuk jangka pendek dan bersifat sementara mana kala sistem pengendalian yang lebih permanen belum dapat diimplementasikan. Jika manajemen keselamatan kerja dapat berjalan dengan baik, risiko kecelakaan pun dapat dikendalikan [10].

\section{Fault Tree Analysis (FTA)}

FTA digunakan untuk melihat reabilitas dari suatu produk dan menunjukan hubungan sebab akibat diantara suatu kejadian dengan kejadian lain. FTA merupakan suatu alat yang sederhana dalam melakukan pendekatan terhadap keamanan dan reliabilitas suatu produk. Untuk membangun model FTA dilakukan dengan mewawancari pihak pekerja lantai produksi dan melakukan pengamatan langsung terhadap proses produksi. FTA adalah sebuah analisis teknik deduktif realibilitas dan analisis keselamatan yang umumnya digunakan untuk dinamis yang kompleks. Seperti yang digunakan saat ini, FTA adalah model yang logis dan grafis yang mewakili berbagai kombinasi dari peristiwa yang tidak diinginkan. FTA menggunakan diagram pohon untuk menunjukan cause-and-effect dari pertistiwa (yang tidak diinginkan dan untuk berbagai penyebab kegagalan) [11].

\section{HASIL DAN PEMBAHASAN}

\section{Metode Hazard Identification and Risk Assessment \& Risk Control (HIRARC)}

Tahapan pertama yang dilakukan dalam pengolahan data menggunakan metode HIRARC, yaitu dengan mewawancarai 1 orang pakar di bagian Health Safety Security Environment, untuk mengidentifikasi bahaya potensial dari suatu proses kerja, menilai tingkat resiko dari segi peluang dan akibat yang ditimbulkan, kemudian menentukan tindakan pengendalian risikonya. Selain melakukan wawancara terhadap pakar, dilakukan juga observasi di lapangan terkhususnya sumur KAS 68/RIG 99, dan analisa terhadap data histori risiko kecelakaan kerja untuk mengidentifikasi kecelakaan kerja. Setelah mengidentifikasi risiko kecelakaan kerja, kemudiaan menilai bahaya (hazard identification), penilaian risiko (risk assesment), dan pengendalian risiko (risk control) menggunakan matriks HIRAR. Tujuan dilakukannya perhitungan matriks HIRARC yakni untuk menentukan risiko kecelakaan kerja paling tinggi, dilihat dari nilai risk level tertinggi yang dihasilkan. Nilai risk level paling tinggi akan dijadikan input dalam analisa menggunakan Fault Tree Analysis (FTA), untuk menentukan akar permasalahan/basic 
event yang mengakibatkan terjadinya kerusakan tersebut. Dari hasil analisa identifikasi dengan menggunakan perhitungan matrix HIRARC, maka risiko kecelakaan kerja pada pekerjaan persiapan material dan fasilitas penunjang dari kegiatan RIG service risiko kecelakaan kerja yang mempunyai risk level tertinggi yaitu;1) Terjatuh, terpeleset (Slips, trips or falls on the same level), terjepit, terpelintir, 2) Banjir/ air tergenang (Cataclysm/bencana alam), 3) Demonstrasi/kerusuhan massa disertai penghadangan/sabotase (protes), 4) Buangan majun bekas terkontaminasi limbah B3, buangan material bekas (hazardous waste generation).

Mengacu pada risiko dengan risk level tertinggi pada hasil perhitungan HIRARC, maka hasilnya akan menjadi objek utama dalam melakukan Fault Tree Analysis, untuk dianalisa lebih lanjut akar penyebab dari kegagalan. Identifikasi bahaya dan penilaian resiko persiapan material dan fasilitas penunjang RIG service dapat dilihat pada Lampiran.

\section{Metode Fault Tree Analysis (FTA)}

Berdasarkan hasil analisis kecelakaan kerja pada pekerjaan persiapan material dan fasilitas penunjang dari kegiatan RIG service di PT Pertamina EP Asset 1 Jambi Field, kejadian puncak yang diambil adalah kecelakaan kerja sedangkan intermediate events kejadian puncak tersebut diambil dari potensi bahaya dengan risk level tertinggi yang telah dihitung menggunakan matrix HIRARC. Setelah mengetahui penyebab dan dampak dari masing-masing potensi bahaya, lalu dibuat diagram fault tree analysis dengan top event kecelakaan kerja (A) yang diuraikan menjadi unsafe act (A1) dan unsafe condition (A2). Lalu dari masing-masing event dibuat diagram fault tree analysis dan aljabar boolean untuk mencari potensi bahaya kerja dominan atau basic events penyebab terjadinya kecelakaan kerja.

Dari bagan fault tree yang telah digambarkan, selanjutnya dicari minimal cut set untuk mengetahui akar permasalahan dari penyebab kecelakaan kerja pada pekerjaan persiapan material dan fasilitas penunjang dari kegiatan RIG service. Cut set merupakan himpunan dari basic events dimana jika semua basic events tersebut muncul, akan terjadi top event. Minimal cut set adalah kombinasi peristiwa yang paling kecil yang membawa peristiwa yang tidak diinginkan. Mencari cut set merupakan analisa kualitatif yang menggunakan Aljabar Boolean.

Kombinasi daripada basic event didapat dari gambar FTA yang dianalisa dengan hubungan and gate atau or gate. Aljabar Boolean merupakan aljabar yang dapat digunakan untuk melakukan penyederhanaan atau menguraikan rangkaian logika yang rumit dan kompleks menjadi rangkaian logika yang lebih sederhana [12]. Perhitungan minimal cut set diperoleh dari penggambaran diagram fault tree di bawah ini:

Hasil dari penggambaran FTA seperti yang diperlihatkan pada Gambar 1 dilakukan untuk mengasumsikan tiap notasi intermediate events dan basic events untuk mempermudah penentuan aljabar Boolean untuk menentukan minimal cut sets. Dimana, top event beserta intermediate events (persegi panjang) yang digambarkan pada FTA dinotasikan dalam urutan abjad A hingga $\mathrm{E}$, sementara basic events (lingkaran) diindikasikan dalam urutan angka 1 hingga 10. Dari Gambar 1, maka diperoleh minimal cut set sebagai berikut:

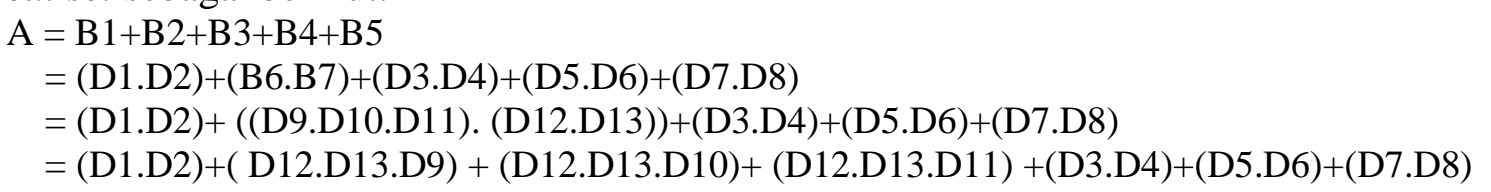

Perhitungan Aljabar Boolean di atas didapat dari tanda "Dan" yaitu Penjumlahan, kemudian tanda "Atau" yaitu perkalian. 


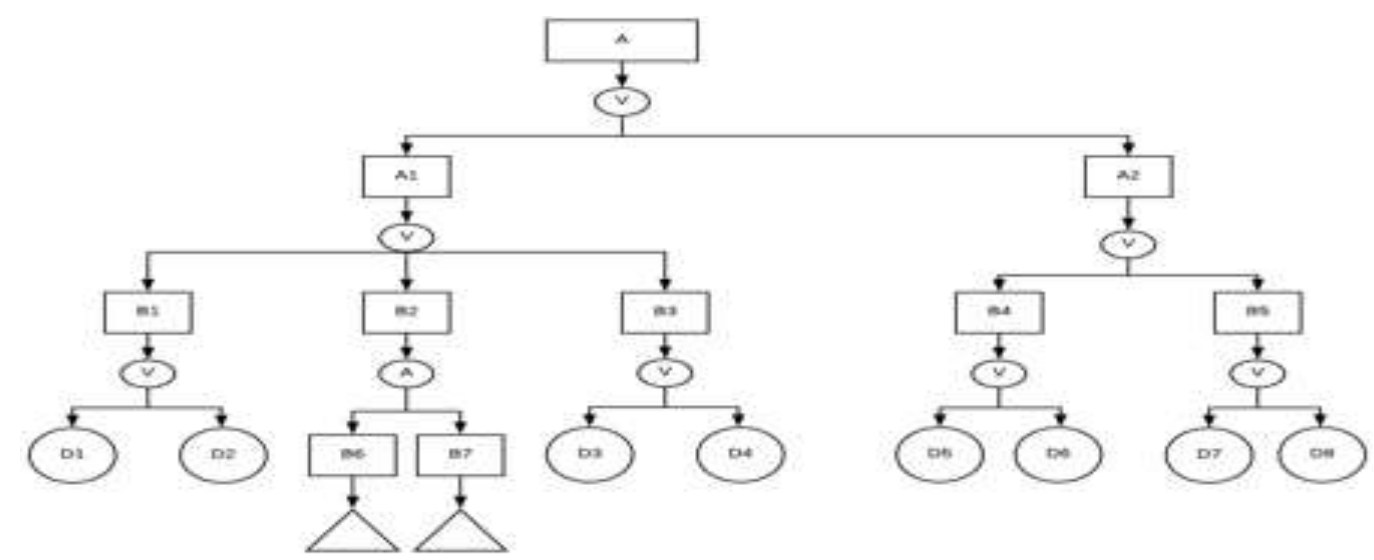

Gambar 1. Fault Tree Analysis Kecelakaan kerja pada kegiatan RIG service

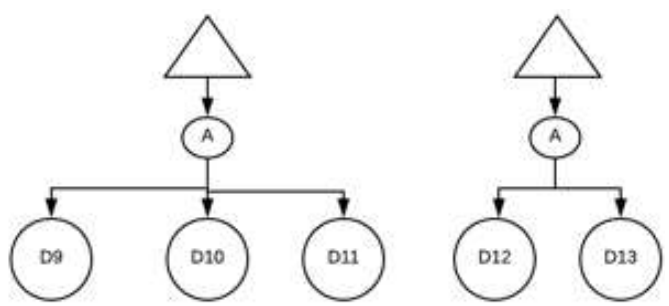

Gambar 2. Fault Tree Analysis Kecelakaan kerja pada kegiatan RIG

Keterangan:

A $=$ Kecelakaan kerja

A1 = Variabel 1, unsafe act

A2 = Variabel 2, unsafe condition

$\mathrm{B} 1$ = Indikator 1, Terjatuh dan Terpleset (Slips, trips or falls on the same level)

$\mathrm{B} 2$ = Indikator 2, Terjepit dan terpelintir

B3 = Indikator 3, Banjir atau Air tergenang (Cataclysm/bencana alam)

B4 = Indikator 4, Demonstrasi/kerusuhan massa disertai penghadangan/sabotase (protes)

B5 = Indikator 5, Buangan majun bekas terkontaminasi limbah B3, buangan material bekas (hazardous waste generation)

B6 = Manajemen yang kurang baik dalam penerapan APD dan APK

$\mathrm{B} 7$ = Tenaga Kerja dalam penerapan APD dan APK UNSAFE

D1 = Tempat kerja yang licin, terjal

D2 = Pekerja yang tidak professional

D3 = Lingkungan yang tidak terkendali dari penyebab Banjir

D4 = Turunnya Hujan dengan intesitas tinggi

D5 = Kurangnya sosialisasi dengan masyarakat setempat

D6 = Keamanan yang tidak ketat, Kurangnya pengawasan

D7 = Manajemen yang kurang baik dalam pencemaran lingkungan

D8 = Pekerja tidak mengetahui limbah B3, buangan material bekas membahayakan lingkungan

D9 = Pekerja tidak menggunakan alat pelindung diri jika melakukan pekerjaan dalam waktu singkat

D10 = Pekerja kurang mengerti cara menggunakan alat pelindung diri yang benar

D11 $=$ Kurang pengawasan perusahaan terhadap penggunaan alat pelindung diri

D12 = Posisi material atau alat yang tidak sesuai dengan ketentuan

D13 = Kurang penerapan pelaksanaan Standar Operational Procedure (SOP) dalam bekerja. 
Tabel 1. Minimal Cut Set

\begin{tabular}{cc}
\hline No & Kombinasi Event \\
\hline 1 & D1.D2 \\
2 & D12.D13.D9 \\
3 & D12.D13.D10 \\
4 & D12.D13.D11 \\
5 & D3.D4 \\
6 & D5.D6 \\
7 & D7.D8 \\
\hline
\end{tabular}

Tabel 2. Hasil Minimal Cut set

\begin{tabular}{ccc}
\hline No & Event & Jumlah \\
\hline 1 & D1.D2 & 1 \\
2 & D9 & 1 \\
3 & D10 & 1 \\
4 & D11 & 1 \\
5 & D12.D13 & 3 \\
6 & D3.D4 & 1 \\
7 & D5.D6 & 1 \\
8 & D7.D8 & 1 \\
\hline
\end{tabular}

Dari hasil aljabar Boolean, didapat 7 minimal cut set yaitu kombinasi dari kejadian dasar/basic event yang menyebabkan terjadinya top event yang di tunjukkan pada Tabel 1.

Penyebab terjadinya kecelakaan kerja pada pekerjaan persiapan material dan fasilitas penunjang dari kegiatan RIG service di PT Pertamina EP Asset 1 Jambi Field adalah: 1) Tempat kerja yang licin dan terjal, Pekerja yang tidak professional. 2) Posisi material atau alat yang tidak sesuai dengan ketentuan,Kurang penerapan pelaksanaan Standar Operational Procedure (SOP) dalam bekerja, Pekerja tidak menggunakan alat pelindung diri jika melakukan pekerjaan dalam waktu singkat, Pekerja kurang mengerti cara menggunakan alat pelindung diri yang benar, Kurang pengawasan perusahaan terhadap penggunaan alat pelindung diri. 3) Lingkungan yang tidak terkendali dari penyebab Banjir, Turunnya Hujan dengan intesitas tinggi. 4) Kurangnya sosialisasi dengan masyarakat setempat, Keamanan yang tidak ketat, Kurangnya pengawasan. 5) Manajemen yang kurang baik dalam pencemaran lingkungan sehingga Pekerja tidak mengetahui limbah B3, buangan material bekas membahayakan lingkungan.

Dari hasil minimal cut set dicari kejadian yang sering muncul sehingga kejadian tersebut merupakan faktor yang dominan penyebab kecelakaan kerja pada pekerjaan persiapan material dan fasilitas penunjang dari kegiatan RIG service di PT Pertamina EP Asset 1 Jambi Field, berikut ditunjukan pada Tabel 3.

Tabel 2 menunjukkan banyaknya jumlah kejadian yang muncul pada minimal cut set yang menyebabkan terjadinya kecelakaan kerja pada RIG service pada pekerjaan persiapan material dan fasilitas penunjang di PT Pertamina EP Asset 1 Jambi Field. Berdasarkan Tabel 2 didapat kejadian D12 dan D13 dengan jumlah kerja yang dominan dari yang lainnya. Sehingga dasar yang menyebabkan terjadinya kecelakaan kerja pada pekerjaan persiapan material dan fasilitas penunjang dari kegiatan RIG service disebabkan oleh Posisi material atau alat yang tidak sesuai dengan ketentuan, Kurang penerapan pelaksanaan Standar Operational Procedure (SOP) dalam bekerja.

\section{KESIMPULAN}

Berdasarkan hasil pembahasan maka dapat disimpulkan bahwa pelaksanaan Kesehatan dan Keselamatan Kerja pada pekerjaan persiapan material dan fasilitas penunjang masih kurang baik mengacu pada kecelakaan kerja yang terjadi di sumur KAS 68/RIG 99 dari kegiatan RIG service serta masih belum menyeluruh dalam melakukan identifikasi potensi risiko kecelakaan kerja, analisis serta tahap pengendalian. Risiko kecelakaan kerja pada pekerjaan persiapan material dan fasilitas penunjang dari kegiatan RIG service yang paling berisiko tinggi dari hasil perhitungan matrix metode HIRARC yakni: terjatuh, terpeleset (Slips, trips or falls on the same level), terjepit dan terpelintir, banjir atau air tergenang (Cataclysm/bencana alam), demonstrasi/kerusuhan massa disertai penghadangan/ sabotase (protes), buangan majun bekas terkontaminasi limbah B3, buangan material bekas (hazardous waste generation). Permasalahan yang menyebabkan 
terjadinya kecelakaan kerja dengan nilai risk level tertinggi berdasarkan penggambaran FTA dan penentuan minimal cut sets didapatkan 2 kombinasi basic events yakni: Posisi material atau alat yang tidak sesuai dengan ketentuan, Kurang penerapan pelaksanaan Standar Operational Procedure (SOP) dalam bekerja.

\section{DAFTAR PUSTAKA}

[1] Anonim. 2014. "1 Orang Pekerja di Dunia Meninggal Setiap 15 Detik Karena Kecelakaan Kerja.” Kementrian Kesehatan Republik Indonesia (www.depkes.go.id). (Diakses pada tanggal 10 Mei 2018).

[2] Ahmad, A.C., Ida N.M.Zin, M.K. Othman, N.H. Muhamad, "Hazard Identification, Risk Assessment \& Risk Control (HIRARC) Accidents at Power Plant". MATEC Web of Conferences 66, 2016, pp. 1-69.

[3] Othman, N., L.L. Lerk, S. Chelliapan, R. Mohammad, \& N.M. Ariff. 2017. Risk Assessment and Control Measures for the Printing Ink Production Process. International Journal of Civil Engineering and Technology, Vol. 8(10), pp. 41-45.

[4] A. Wijaya, T.W.S. Panjaitan, H.C. Palit, "Evaluasi Kesehatan dan Keselamatan Kerja dengan Metode HIRARC pada PT Charoen Pokhand Indonesia”, Jurnal Titra, Vol.3 No.1, 2015, pp. 29-34.

[5] A.M. Saedi, J.J. Thambirajah, A. Pariatamby."A HIRARC model for safety and risk evaluation at a hydroelectric power generation plant", Safety Science, Volume 70, 2014, pp.308-315.

[6] V.E. Laksana, W. Kosasih, C.O.Doaly, "Analisis Potensi Bahaya Menggunakan Metode HIRADC sebagai Upaya Pencegahan Kecelakaan Kerja (Studi Kasus: PT. Supreme cable Manufacturing \& Commerce)", Prosiding SNTS III, Oktober 2018, pp. 251-257.

[7] Nurmawanti, I., Widaningrum, S., Iqbal, M. 2013. Identifikasi Keselamatan Dan Kesehatan Kerja (K3) Dengan Menggunakan Metode Hirarc Untuk Memenuhi Requirement Ohsas 18001: 2007 Terkait Klausul 4.4.6 Di Pt. Beton Elemenindo Perkasa. Jurnal Teknik Elektro Universitas Telkom.

[8] Occupational Health \& Safety Standard 18001 Tahun 2007 tentang Sistem Manajemen Keselamatan dan Kesehatan Kerja - Persyaratan. (http://www.producao.ufrgs.br/arquivos/disciplinas/103_ohsas_18001_2007_ing.pdf) diakses pada 10 September - 30 September 2018.

[9] Ramli S. Sistem Manajemen Keselamatan dan Kesehatan Kerja. Jakarta: Dian Rakyat; 2009.

[10] Gunawan, F.A., dkk. 2016. Manajemen Keselamatan Operasi: Membangun Keunggulan Operasi dalam Industri Proses. Jakarta: PT. Gramedia Pustaka Utama.

[11] T. K. Tiffani, "Analisa Penyebab Penurunan Daya Saing Produk Susu Sapi Dalam Negeri Terhadap Susu Sapi Impor Pada Industri Pengolahan Susu (IPS) Dengan Metode Fault Tree Analysis (FTA) dan Barrier Analysis”, JTI UNDIP, Vol. 6 No. 2. 2011.

[12] Widjanarka, Wijaya.Teknik Digital Jakarta: Erlangga. 2006. 
Analisis Risiko Kecelakaan Kerja pada Kegiatan RIG Service Menggunakan Metode HIRARC dengan Pendekatan FTA

Siti Nurlelyza Trisaid

\section{Lampiran}

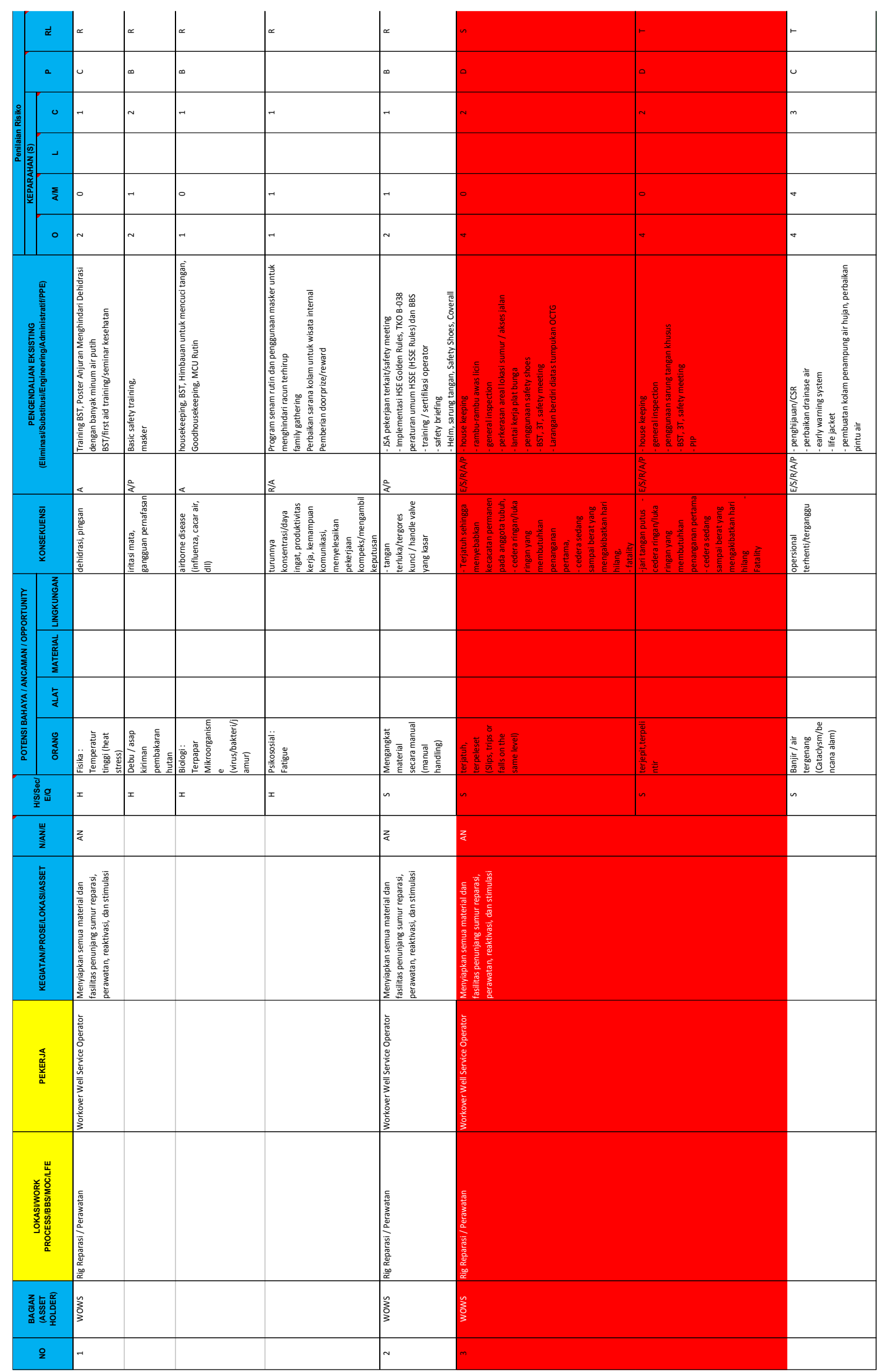




\section{Lanjutan Lampiran}

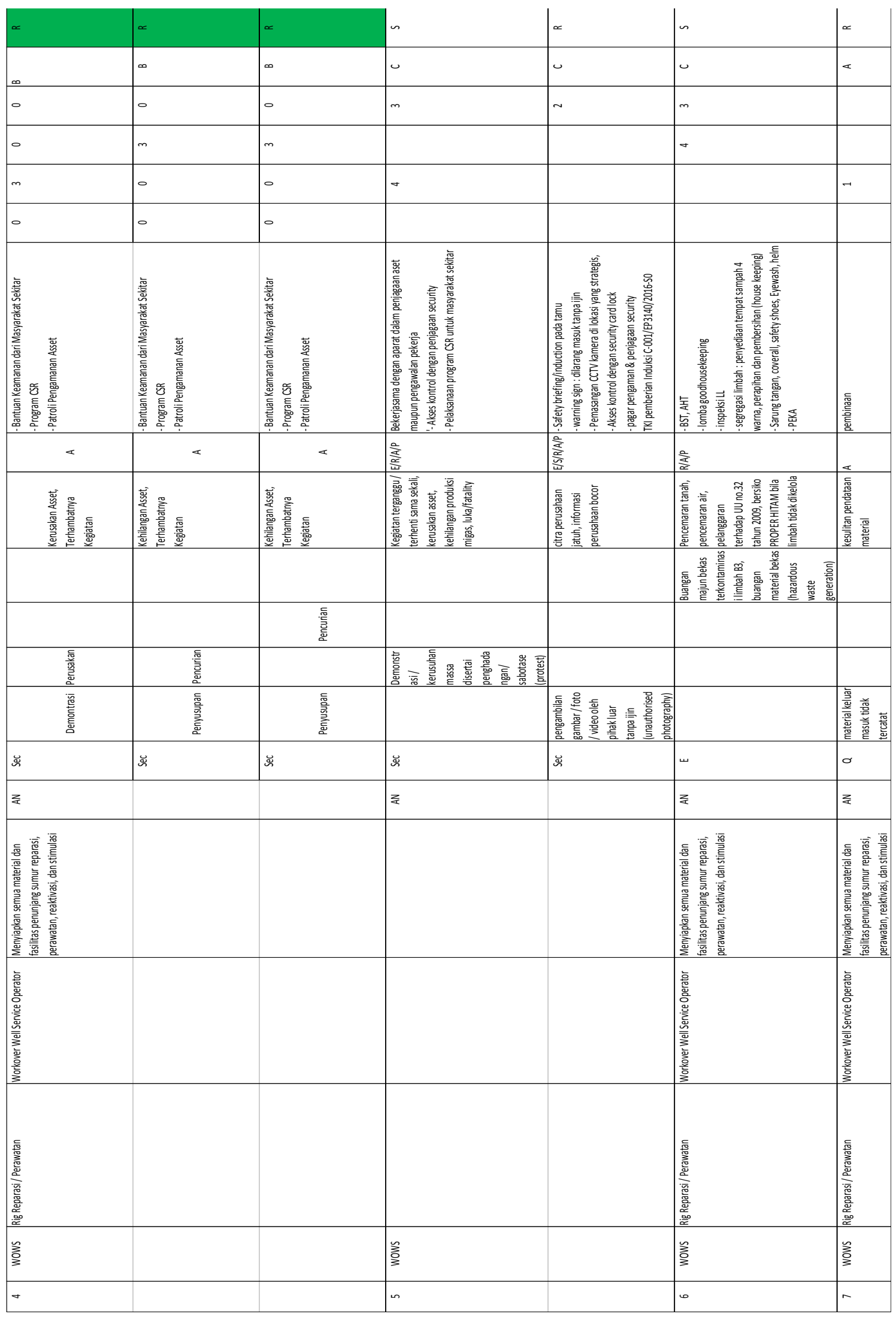

